\title{
Analysis of Helicobacter pylori positiveness and upper gastrointestinal system endoscopy results of Yozgat region in Turkey
}

\author{
Tekin Yıldırım, @Muhammed Alperen Dursun \\ Yozgat BozokUniversity, Faculty of Medicine, Department of Internal Medical Sciences, Yozgat, Turkey
}

Cite this article as: Ylldırım T, Dursun MA. Analysis of Helicobacter pylori positiveness and upper gastrointestinal system endoscopy results of Yozgat region in Turkey. J Health Sci Med 2021; 4(6): 901-906.

\begin{abstract}
Aims: The aim of this study is to analyze the endoscopy and pathology results of patients who underwent endoscopy in Yozgat region, to determine the frequency of Helicobacter pylori (H. pylori) positivity and to compare the results with the data in the literature.

Material and Method: Among the patients who applied to our clinic for any reason between 01/01/2019 and 31/12/2019, 772 patients who underwent upper gastrointestinal system endoscopy were included in the study and analyzed retrospectively.

Results: The mean age of the patients was $50 \pm 16.78(16-89) .61 .3 \%(n=473)$ of the patients were female; $38.7 \%(n=299)$ were male. When gastroscopic diagnoses were evaluated, the rate of patients reported as "normal upper gastrointestinal endoscopy" was found to be $5.2 \%(n=40)$. The most frequently reported diagnosis was "nonerosive gastritis" with a rate of 59.2\% ( $n=457)$. Biopsy was obtained in 646 of 772 patients. The most common diagnosis was reported as "chronic active gastritis" with 90.6\% ( $\mathrm{n}=585) .626$ of the patients had H. pylori pathological evaluation results. While 18.7\% ( $\mathrm{n}=117)$ of the patients were found to be $H$. pylori negative, $81.3 \%(\mathrm{n}=509)$ were found to be $H$. pylori positive. Stomach cancer was found to be $1.3 \%(\mathrm{n}=9)$ and esophageal cancer was found to be $0.1 \%(n=1)$.

Conclusion: In the Yozgat region, the frequency of $H$. pylori positivity was found to be $81.3 \%$, and it is often mildly $(+)$ positive. In addition, the frequency of $H$. pylori positivity was similar between men and women, consistent with the literature. The most common diagnosis was reported as "chronic active gastritis". While stomach cancer was detected at a rate of $1.3 \%$, esophageal cancer was found at a rate of $0.1 \%$.
\end{abstract}

Keywords: Upper gastrointestinal endoscopy, Helicobacter pylori, histopathology, gastric cancer, esophageal cancer

\section{INTRODUCTION}

Upper gastrointestinal endoscopy (Esophagogastroduodenoscopy) is the most reliable diagnostic method widely used in the diagnosis of esophageal, stomach and proximal duodenal diseases. The advantage of endoscopy is to see the inner surface of the organ directly, to perform pathological sampling from the lesions, and to apply endoscopic treatment when necessary. For treatment purposes, interventional procedures such as excision of the polyp, control of upper and lower gastrointestinal system bleeding (esophageal varices bleeding, sclerotherapy, coagulation), and removal of foreign bodies can be performed (1).

The most common symptoms of upper gastrointestinal system diseases can be detected as dysphagia, dyspepsia, nausea and vomiting, retrosternal burning, epigastric pain, bleeding, and weight loss. These symptoms may indicate a benign or malignant condition. Therefore, patients with these symptoms should be evaluated with endoscopy $(2,3)$.

H. pylori is a frequently encountered gram-negative pathogenic bacterium that affects almost half of the world population (4). H. pylori is implicated as an important pathogen in some diseases; chronic gastritis, peptic ulcer, nonulcer dyspepsia, gastric carcinoma and MALT lymphoma are the main ones (5). It is estimated that $50-90 \%$ of the world population is infected with $H$. pylori $(6,7)$. 
H. pylori is a human pathogen that is transmitted from person to person and causes chronic active gastritis (of varying severity) in all colonized subjects. H. pylori gastritis is considered an infectious disease regardless of the symptoms of the individual and the stagecomplications of the disease (8). In 1994, when the World Health Organization International Agency for Research on Cancer concluded that $H$. pylori is a definite carcinogen in humans, attention was focused on this bacterium (9). The need for endoscopy is increasing due to increasing gastrointestinal malignancies, increased frequency of $H$. pylori and widespread screening programs.

The gold standard for the diagnosis of $H$. pylori is the histopathological examination of the samples taken by gastroscopic biopsy and the demonstration of the bacterium by culture $(10,11)$.

In this study, we aimed to retrospectively determine and present the frequency of esophageal, stomach and proximal duodenum diseases and the frequency of $H$. pylori in endoscopic biopsy samples, and its relationship with age and gender in patients admitted to a tertiary hospital and undergoing upper gastrointestinal system endoscopy.

\section{MATERIAL AND METHOD}

The study was carried out with the permission of Yozgat Bozok University Clinical Research Ethics Committee (Date: 14.04.2021, Decision No: 2017-KAEK189_2021.04.14_04). All procedures were carried out in accordance with the ethical rules and the principles of the Declaration of Helsinki.

In our study, 772 patients who underwent upper gastrointestinal endoscopy for any reason in the endoscopy unit of a tertiary hospital between 01/01/2019 and 31/12/2019 were retrospectively analyzed. The patients' endoscopy reports, tissue biopsy pathology reports and other information were obtained from hospital records.
It was observed that all endoscopic procedures were performed under pharyngeal local anesthesia and sedated anesthesia (propofol i.v.) after 8 hours of fasting. The age, gender and esophagus, stomach and proximal duodenum findings in the endoscopy reports of the patients were determined.

Biopsy preparations taken for $H$. pylori and histopathological diagnosis were stained with hematoxylin-eosin and modified giemsa and examined under light microscopy, and reported as $(+)$ mild, $(++)$ moderate, $(+++)$ severe positive according to the bacterial density in the preparations. It was observed that PNL activation, Hp activity, chronic inflammation, intestinal metaplasia, presence of atrophy were graded according to Sydney classification (Table 1) (12). It was observed that more advanced staining and techniques were used in malignant cases. Pathological data were obtained from these reports.

\section{Statistical Analysis}

SPSS version 20.0 (Statistical Package for Social Sciences) program was used for statistical analysis of the findings. Descriptive statistics were used in the analysis of the data. While continuous variables were expressed as mean \pm standard deviation (SD), nominal variables were expressed as percentages. Chi-square test and MannWhitney $U$ test were used to evaluate the relationship between groups. $P$ value $<0.05$ was considered statistically significant.

\section{RESULTS}

When the retrospective files were scanned, it was determined that 772 patients underwent upper gastrointestinal endoscopy between 01/01/2019 and $31 / 12 / 2019$. The mean age of the patients was $50 \pm 16.78$ $(16-89) .61 .3 \%(n=473)$ of the patients were female; $38.7 \%(\mathrm{n}=299)$ were male.

When gastroscopic diagnoses were evaluated, the rate of patients reported as "normal upper gastrointestinal endoscopy" was found to be $5.2 \%(n=40)$. The most

\begin{tabular}{|c|c|c|}
\hline Feature & Definition & Garding guidelines \\
\hline $\begin{array}{l}\text { Chronic } \\
\text { inflammation }\end{array}$ & $\begin{array}{l}\text { Increased lymphocytes and plasma cells in the } \\
\text { lamina propria }\end{array}$ & Mild, moderate, or severe increase in density \\
\hline Activity & $\begin{array}{l}\text { Neutrophilic infiltrates of the laminapropria, } \\
\text { pits, or surface epithelium }\end{array}$ & $\begin{array}{l}\text { Mild: }<1 / 3 \text { of pit and surface infiltrated } \\
\text { Moderate: } 1 / 3-2 / 3 \text { of pit and surface infiltrated } \\
\text { Severe: }>2 / 3 \text { of pit and surface infiltrated }\end{array}$ \\
\hline Atrophy & $\begin{array}{l}\text { Loss of specialized glands from either antrum } \\
\text { or corpus }\end{array}$ & $\begin{array}{l}\text { Mild: mild loss } \\
\text { Moderate: moderate loss } \\
\text { Severe: severe loss }\end{array}$ \\
\hline $\begin{array}{l}\text { Intestinal } \\
\text { metaplasia }\end{array}$ & Intestinal metaplasia of the epithelium & $\begin{array}{l}\text { Mild: }<1 / 3 \text { of mucosa involved } \\
\text { Moderate: } 1 / 3-2 / 3 \text { of mucosa involved } \\
\text { Severe: }>2 / 3 \text { of mucosa involved }\end{array}$ \\
\hline $\begin{array}{l}\text { Helicobacter } \\
\text { pylori }\end{array}$ & Density of $H$. pylori overlying epithelium & $\begin{array}{l}\text { Mild: scattered organism covering }<1 / 3 \text { of surface } \\
\text { Moderate: intermediate numbers } \\
\text { Severe: large cluster or a continuous layer over }>2 / 3 \text { of surface }\end{array}$ \\
\hline
\end{tabular}


frequently reported diagnosis was "nonerosive gastritis" with a rate of $59.2 \%(n=457)$. Gastric ulcer rate was $6 \%$ $(n=46)$; duodenal ulcer rate was found to be $2.3 \%(n=17)$. A mass lesion suggesting malignancy in the stomach was found to be $1.3 \%(n=10)$. Esophagitis was reported as $23.4 \%(n=181)$, varicose veins in the esophagus $0.8 \%$ $(n=6)$ and a mass lesion suggesting malignancy in the esophagus was reported as $0.1 \%(n=1)$ (Table 2).

\begin{tabular}{|c|c|c|}
\hline Endoscopic Diagnoses & $\begin{array}{l}\text { Number of } \\
\text { patients (n) }\end{array}$ & $\begin{array}{c}\text { Patient } \\
\text { ratio (\%) }\end{array}$ \\
\hline Normal Endoscopy & 40 & 5.2 \\
\hline Nonerosive Gastritis & 457 & 59.2 \\
\hline Pangastritis & 44 & 5.7 \\
\hline Erosive Gastritis & 42 & 5.4 \\
\hline Alkaline Reflu Gastritis & 49 & 6.3 \\
\hline Gastric Ulcer & 46 & 6 \\
\hline Gastric Malignant Mass Lesion & 10 & 1.3 \\
\hline Gastric Polyp & 14 & 1.8 \\
\hline Bulbit & 33 & 4.3 \\
\hline Duodenal Ulcer & 17 & 2.2 \\
\hline Esophagitis & 181 & 23.4 \\
\hline Lower Esophageal Sphincter Slackness & 178 & 23 \\
\hline Hiatal Hernia & 11 & 1.4 \\
\hline Esophageal Varicose & 6 & 0.8 \\
\hline Esophageal Diverticulum & 1 & 0.1 \\
\hline Esophageal Malignant Mass Lesion & 1 & 0.1 \\
\hline İnlet Patch & 10 & 1.3 \\
\hline
\end{tabular}

When the pathological diagnoses were examined, it was determined that biopsy was taken in 646 of 772 patients. The most common diagnosis was reported as "chronic active gastritis" with $90.6 \%(\mathrm{n}=585)$. It was observed that chronic atrophic gastritis was reported with a rate of $4.8 \%(n=31)$. Gastric adenocarcinoma rate was $1.2 \%$ $(\mathrm{n}=8)$, neuroendocrine tumor rate was $0.1 \%(\mathrm{n}=1)$, and esophageal squamous cell cancer rate was $0.1 \%(\mathrm{n}=1)$ (Table 3).

Table 3. Reported pathological diagnoses, patient numbers and rates

\begin{tabular}{|lcc|}
\hline Endoscopic Diagnoses & $\begin{array}{c}\text { Number of } \\
\text { patients (n) }\end{array}$ & $\begin{array}{c}\text { Patient } \\
\text { ratio (\%) }\end{array}$ \\
\hline Chronic Active Gastritis & 585 & 90.6 \\
Chronic Atrophic Gastritis & 31 & 4.8 \\
Stomach Adenocarcinoma & 8 & 1.2 \\
Gastric Neuroendocrine Tumor & 1 & 0.1 \\
Hyperplastic adenoma & 8 & 1.2 \\
Tubular Adenoma & 2 & 0.2 \\
Tubulovillous Adenoma & 1 & 0.1 \\
Xanthelasma & 1 & 0.1 \\
Esophageal Columnar Metaplasia & 2 & 0.2 \\
Squamous Cell Carcinoma of the & 1 & 0.1 \\
Esophagus & 2 & 0.2 \\
Celiac Disease & & \\
\hline
\end{tabular}

626 of the patients had $H$. pylori pathological evaluation results. While $18.7 \%(\mathrm{n}=117)$ of the patients were found to be $H$. pylori negative, $81.3 \%(n=509)$ were found to be $H$. pylori positive. The rates of positivity degrees according to Sydney Classification in H. pylori positive patients are given in Table 4.

Table 4. Rates of Helicobacter pylori positivity according to Sydney classification

\begin{tabular}{|lcc|}
\hline Degree of Positivity & $\begin{array}{c}\text { Number of } \\
\text { patients }(\mathbf{n})\end{array}$ & $\begin{array}{c}\text { Rate of } \\
\text { patients (\%) }\end{array}$ \\
\hline Helicobacter pylori +1 & 379 & 74.5 \\
Helicobacter pylori +2 & 103 & 20.2 \\
Helicobacter pylori +3 & 27 & 5.3 \\
\hline
\end{tabular}

When the relationship between $H$. pylori status and gender was examined, it was found that there was no significant relationship $(\mathrm{p}=0.595)$. When the relationship between $H$. pylori status and age was examined, it was found that there was no significant relationship $(\mathrm{p}=0.195)$.

When metaplasia was examined, metaplasia was found in $8.6 \%(n=53)$ of 615 patients. When atrophy was examined, it was found that $16.3 \%(n=100)$ of 613 patients had atrophy.

\section{DISCUSSION}

In addition to the use of upper gastrointestinal endoscopy for diagnostic purposes in esophagus, stomach and proximal duodenal diseases, its therapeutic use is becoming widespread with the development of therapeutic endoscopes.

Esophageal cancer is the $8^{\text {th }}$ most common cancer in the world and ranks $6^{\text {th }}$ in cancer-related deaths (13). Esophageal cancers are more common in developing countries and these cancers are usually detected at an advanced stage (inoperable period). Esophageal cancer is more common in males. According to 2013 statistical data in Turkey, the incidence of esophageal cancer is 1.3 per hundred thousand in women and 2.1 per hundred thousand in men (14).

In studies conducted in our country, the incidence of esophageal cancer shows regional differences. Esophageal cancer was detected in $4.3 \%$ of the patients who underwent endoscopy in the study conducted in the Van basin in the Eastern Anatolia Region. 61\% of the patients were women and $39 \%$ were men, and esophageal cancer was 1.5 times more common in women than in men. The mean age was determined as 54.7 (15). In a study conducted in the Harran Region, the incidence of esophageal cancer was found to be $0.2 \%$ in a series of 5286 patients (16). In a study evaluating 6912 upper gastrointestinal endoscopy performed in the Elazig region, esophageal cancer was reported as $0.1 \%$. 
In a study conducted in the Western Black Sea Region, the rate of esophageal cancer was reported as $0.06 \%$ in 7703 patients who underwent upper gastrointestinal endoscopy (17). In a study conducted in Aydin Region, upper gastrointestinal malignancy was detected with a rate of $2.71 \%$ in endoscopic examinations (18). In our study, the detection rate of esophageal cancer in the Yozgat Region was found to be $0.1 \%(n=1)$.

While gastric cancer is the fourth most common type of cancer in the world, it ranks third in cancer-related deaths (19). Gastric cancer is the most common type of cancer in women after breast and colorectal cancers in our country. In men, it is the most common type of cancer after lung cancer. In general, it occurs twice as often in men than in women. The average age of occurrence is between 60-70 years $(20,21)$. The incidence of gastric cancer in our country varies between $0.5-4 \%$ (17). In a study involving 504 gastric cancers in Erzurum Region, 36.1\% of gastric cancer patients were female and $63.9 \%$ male, and the mean age of the patients was 62.4 years (22). In a study conducted in the Elazig Region, gastric cancer was detected with a rate of $1.3 \%$ in upper gastrointestinal endoscopy (17). In a study conducted in the Harran Region, the frequency of gastric cancer was found to be $0.5 \%$ in a series of 5286 patients (16). Gastric cancer in the Van Region was found 1.6 times more frequently in men than in women. The mean age of the cases was 54.8 , and it was most common between the ages of 51-60 (39\%) (15). In our study, the incidence of gastric cancer was $1.3 \%(n=9)$ in 772 patients who underwent upper gastrointestinal endoscopy. The findings are similar to the literature. Gastric adenocarcinoma was detected in 8 patients, and gastric neuroendocrine tumor was detected in 1 patient.

There are various diagnostic methods used in the detection of $H$. pylori infection. These methods are divided into invasive methods that require endoscopic gastric mucosal biopsy and noninvasive methods that do not require endoscopy. Invasive tests; culture, histopathological test, rapid urease test and PCR. Noninvasive tests consist of Urea breath test, serological tests and Helicobacter pylori antigen in stool $(10,11)$.

In studies conducted in different regions of Turkey and on different dates, it has been reported that the frequency of $H$. pylori is found to be between 43$88.6 \%$, the frequency varies between regions and age groups, and tends to decrease with age in recent years (23-37). Özardalı et al. (28) in 1998, Uyanıkoğlu et al. (24) in 2012, in their study covering the Sanliurfa region and including cases with different endoscopic diagnoses; reported $H$. pylori positivity as $89.8 \%$ and $71 \%$, respectively. Konakçı et al. (23) found $H$. pylori positivity in $50.5 \%$ of 218 patients who underwent endoscopic biopsy due to dyspepsia complaint in 2010. In studies conducted in Konya region, while Kesli et al. (29) found $H$. pylori positive in $36.6 \%$ of 168 patients who applied with dyspepsia complaints and underwent endoscopic gastric biopsy in 2010, Korkmaz et al. (30) found $H$. pylori positive in $45.4 \%$ of 198 dyspepsia patients who underwent endoscopy in 2012. In studies conducted between 2003 and 2008, the prevalence of $H$. pylori antigen was reported as 70.1\% (30) in Sivas, 64\% - $44.2 \%(32,33)$ in Konya, and 58.4\% (34) in Kayseri. The most comprehensive study on epidemiological studies on $H$. pylori in adults in our country is the TURHEP study conducted in 2003. In this study, the general prevalence of $H$. pylori was found to be $82.5 \%$ using the urea breath test in 5.549 adults over the age of 18 , and the prevalence was found to be $84 \%$ in men and $81 \%$ in women (35). Again, in the study of Çiftel et al. (36) involving 653 patients in Erzurum region, H. pylori positivity was found to be $57.7 \%$ and it was reported as mild $(+)$ positive in $58.7 \%$ of the patients with $H$. pylori. When the literature is examined in terms of positivity and clinical and laboratory results, not many studies have been found. Only Dağlı et al. (37) found a relationship between the degree of $H$. pylori positivity and mast cell density, which is known to be the primary trigger of inflammation. In our study, $H$. pylori was examined histopathologically in patients whose biopsy was taken. In addition to the presence of $H$. pylori, its density was also examined. In our study, $H$. pylori was found to be positive in $81.3 \%$ of the patients who underwent endoscopy by histopathological examination. The degree of $H$. pylori positivity was mildly $(+)$ positive with a rate of $74.5 \%$ in line with the literature, and the frequency of $H$. pylori positivity between women and men was similar as in the literature (36).

The difference in the frequency of $H$. pylori positivity in studies may be due to the presence of various risk factors in the studied population, such as environmental reasons, hygiene, low education level, regional backwardness, previous gastrointestinal endoscopy, and less eradication. Megraud et al. (38) showed that with the increase in the incidence of atrophic gastritis in advanced ages, $H$. pylori lost its ecological home and its frequency decreased. Low education level, regional backwardness, hygiene and less eradication may be the main factors due to the high $H$. pylori positivity rates in our region.

Approximately one million people worldwide die from diseases associated with $H$. pylori every year (39). Considering that $H$. pylori is the main etiological factor especially in gastric cancer and its associated other diseases and its frequency in the general population, it is estimated that $H$. pylori infection will remain on the 
agenda as the leading health problem in developing countries for the next 50 years $(11,39)$. For this reason, it becomes necessary to monitor the changes in the frequency of $H$. pylori and to make its eradication. Expecting a reduction in the incidence of gastric cancer with the eradication of $H$. pylori seems to be the most effective and cost-effective method.

Gastric polyps are detected incidentally during the endoscopy procedure. In a study involving 13 thousand patients, the prevalence of gastric polyps was found to be $1.2 \%$ (40). In a study conducted in the Kirıkkale region of our country, the frequency of gastric polyps was found to be $1.5 \%$ (41). In our study, it was found to be $1.8 \%$.

In studies conducted in our country, while the frequency of gastric ulcer was $10 \%$ and duodenal ulcer frequency was found to be $11 \%$ in Şanliurfa region, the frequency of gastric ulcer was $9 \%$ and duodenal ulcer frequency was found to be $15 \%$ in Aydin region $(42,43)$. In our study, the frequency of gastric ulcer was $6 \%$ and the frequency of duodenal ulcer was $2.2 \%$ in the Yozgat region.

\section{CONCLUSION}

The frequency of $H$. pylori was found to be $81.3 \%$ in Yozgat region and it was often mildly positive $(+)$. In addition, the prevalence of $H$. pylori was similar between men and women, consistent with the literature. The most common diagnosis was reported as "chronic active gastritis". Gastric ulcer frequency was $6 \%$, duodenal ulcer frequency was $2.2 \%$, gastric poly frequency was $1.8 \%$, gastric cancer was $1.3 \%$, and esophageal cancer was $0.1 \%$. As a result, with this study, we have presented the upper gastrointestinal endoscopy data of our region to the literature and it is the first study conducted in the Yozgat region.

\section{ETHICAL DECLARATIONS}

Ethics Committee Approval: The study was carried out with the permission of Yozgat Bozok University Clinical Researchs Ethics Committee (Date: 14.04.2021, Decision No: 2017-KAEK-189_2021.04.14_04).

Informed Consent: Because the study was designed retrospectively, no written informed consent form was obtained from patients.

Referee Evaluation Process: Externally peer-reviewed.

Conflict of Interest Statement: The authors have no conflicts of interest to declare.

Financial Disclosure: The authors declared that this study has received no financial support.

Author Contributions: All of the authors declare that they have all participated in the design, execution, and analysis of the paper, and that they have approved the final version.

\section{REFERENCES}

1. Loffeld R, Van der Putten A. The yield of UGIE: a study of a tenyear period in the 'Zaanstreek'. Neth J Med 2003; 61: 14-8.

2. Tamer A, Korkut E, Korkmaz U. Upper gastrointestinal endoscopy results in Düzce region. Med J Kocatepe 2005; 6: 31-4.

3. Nur N, Yllmaz A, Ylldız G. Characteristics of patients with gastrointestinal bleeding, evaluation of endoscopy and biopsy results. Journal of the CU Faculty of Medicine 2007; 29: 42-6.

4. Kaplan M, Tanoglu A, Düzenli T, Tozun AN. Helicobacter pylori treatment in Turkey: Current status and rational treatment options. North Clin Istanb 2020; 7: 87-94.

5. Hunt RH. The role of Helicobacter pylori in pathogenesis: the spectrum of clinical outcomes. Scand J Gastroenterol 1996; 31: 3-9.

6. Lehours P, Yilmaz O. Epidemiology of Helicobacter pylori infection. Helicobacter 2007; 12: 1-3.

7. Yücel T, Aygın D, Sen S, Yücel O. The prevalence of Helicobacter pylori and related factors among university students in Turkey. Jpn J Infect Dis 2008; 61: 179-83.

8. Malfertheiner P, Megraud F, O'Morain CA on behalf of the European Helicobacter and Microbiota Study Group and Consensus panel, et al Management of Helicobacter pylori infection-the Maastricht V/Florence Consensus Report Gut 2017; 66: 6-30.

9. [No authors listed]. Schistosomes, liver flukes and Helicobacter pylori. IARC Working Group on the Evaluation of Carcinogenic Risks to Humans. Lyon, 7-14 June 1994. IARC Monogr Eval Carcinog Risks Hum 1994; 6: 1-241.

10.McNulty C.A, Lehours P, Mégraud F. Diagnosis of Helicobacter pylori Infection. Helicobacter 2011; 16: 10-18.

11. Granstrom M, Lehours P, Bengtsson C, Mégraud, F. Diagnosis of Helicobacter pylori. Helicobacter 2008; 13: 7-12.

12. Tonkic A, Tonkic M, Lehours P, Mégraud F. Epidemiology and diagnosis of $H$. pylori infection. Helicobacter 2012; 17: 1-8.

13. Siegel RL, Miller KD, Jemal A. Cancer statistics, 2015. CA Cancer J Clin 2015; 65: 5-29.

14. Gültekin M, Boztaş G, Utku EŞ. Turkey cancer statistics. Eds İ. Şencan, GN İnce T.C. Ministry of Health Turkish Public Health Institution 2016; 19.

15. Tuncer İ, Uygan İ, Kösem $M$, et al. Demographic and histopathological features of upper gastrointestinal system cancers in Van and its surroundings. Van Med J 2001; 8: 10-3.

16.Cevheri Ağan Z, Cindoğlu Ç, Ağan V, Uyanıkoğlu A, Yenice $\mathrm{N}$. Analysis of demographic data of patients who underwent esophagogastroduodenoscopy in Harran University Gastroenterology Clinic: 5-year series. Harran University Med J 2019; 16: 101-4.

17. Polat Y. Endoscopic experience of a surgeon: The evaluation of 8453 cases. Int J Basic Clin Med 2015; 3: 1-5.

18. Coşkun A, Borazan S, Yükselen V et al. Features of upper gastrointestinal tract malignancies in Aydin region. Endoscopy Gastrointestinal 2015; 23: 67-9.

19. Ferlay J, Soerjomataram I, Dikshit R, et al. Cancer incidence and mortality worldwide: sources, methods and major patterns in Globocan 2012. Int J Cancer 2015; 136: 359-86.

20. Yalçın B, Zengin N, Aydın F. The clinical and pathological features of patients with gastric cancer in Turkey: A Turkish Oncology Group Study. Turk J Cancer 2006; 36: 108-15.

21.Göçmen E, Kocaoğlu H. Gastric cancer epidemiology. T Klin J Surg 2000; 5: 161-2.

22.Kısaoğlu A, Özoğul B, Yıldırgan Mİ, et al. Surgery in stomach cancer: 504 cases. Abant Med J 2014; 3: 220-5.

23. Konakc1 N, Gülten M, İbanoğlu MS, et al. The frequency of Helicobacter pylori in patients with chronic active gastritis. Journal of Uludag University Medicine Faculty 2010; 36: 7-10. 
24. Uyanıkoğlu A, Coskun M, Binici DN, et al. The frequency of Helicobacter pylori in patients undergoing endoscopy. Dicle Med J 2012; 39: 197-200.

25. Karaaslan H, Bektaş M, Soykan İ, Bozkaya H, Bahar K, Özden A. Helicobacter pylori seroprevalence in volunteer blood donors in Turkey. Türk J Gastroenterol 2003; 14: SBO3/1.

26. Göral V, Özdal B, Kaplan A, Şit D, Danıș R. Helicobacter pylori antibody prevalence in Diyarbakır province. The Turkish Journal of Academic Gastroenterology 2005; 5: 47-50.

27. Bulut M, Armağan E, Kıyıcı M, Balcı V, Atar N, Gürel S. The frequency of Helicobacter pylori in patients presenting to the emergency department with epigastric pain and the role of qualitative serum IgG test in diagnosis. Journal of Uludag University Medicine Faculty 2004; 30: 7-10.

28. Özardalı Hİ, Bitiren M, Nazlıgül Y, Yılmaz N. The frequency of Helicobacter pylori in nonerosive gastritis in Şanlıurfa region. Genel Tip Derg 1998; 8: 149-52.

29. Kesli R, Göktürk HS, Erbayrak M, Karabağlı P, Terzi Y. Comparison of the diagnostic values of the 3 different stool antigen tests for the noninvasive diagnosis of Helicobacter pylori infection. J Investig Med 2010; 58: 982-6.

30. Korkmaz H, Kesli R, Karabağlı P, Terzi Y. Comparison of the diagnostic accuracy of five different stool antigen tests for the diagnosis of Helicobacter pylori infection. Helicobacter 2013; 18 384-91.

31. Alim A, Ataş AD, Güneş T, et al. Helicobacter pyloriseroprevalence in symptomatic and asymptomatic adults in Sivas province. Journal of the Faculty of Medicine Cumhuriyet University 2004; 26: $75-80$

32. Kalem F, Özdemir M, Baysal B. Investigation of the presence of Helicobacter pyloriby different methods in patients with dispeptic complaints. Mikrobiyol Bult 2010; 44: 29-34.

33. Özdemir M, Baykan M. Investigation of the diagnostic value of $H$. pylori stool antigen in the diagnosis of $H$. pylori infection in dyspeptic patients. Genel Tip Derg 2005; 15: 65-70.

34. Arslan D, Tahan F, Demir F, Taşkın İ. Seroprevalence of Helicobacter pylori infection in healthy children admitted to Erciyes University Faculty of Medicine Pediatrics Outpatient Clinic and the factors affecting it. Erciyes Med J 2006; 28: 192-6.

35. Ozaydin N, Turkyilmaz SA, Cali S. Prevalence and risk factors of Helicobacter pylori in Turkey: a nationally-representative, crosssectional, screening with the $13 \mathrm{C}$-Urea breath test. BMC Public Health 2013; 13: 1215.

36. Çiftel S, Okçu N, Dursun H, Albayrak F, Usta S. The frequency of Helicobacter pylori in our region. Güncel Gastroenteroloji, 2016; 20/2: 157-160

37.Dağlı AF, Cihangiroğlu G, Çobanoğlu B, Özercan İH, Bahçecioğlu IH, Özercan MR. The relationship between Helicobacter pylori density and mast cell count in antral gastritis. Firat Med J 2006; 11: 48-50.

38. Megraud F. Epidemiology of Helicobacter pylori infection: Helicobacter pylori. Gastroenterology Clin Nort America 1993; 22: 73-88.

39. Ferlay J, Soerjjomataram I, Dikshit R, et al. Cancer incidence and mortality worldwide: souces, methods and major patterns in GLOBOCAN 2012. Int J Cancer 2015; 136: E359-86.

40. Archimandritis A, Spiliadis C, Tzivras M, et al. Gastric epithelial polyps: a retrospective endoscopic study of 12974 symptomatic patients. Ital J Gastroenterol, 1996; 28: 387-90.

41.Güliter S, Keles H, Özkurt ZN. Kırıkkale University Faculty of Medicine Internal Diseases Clinic Upper Gastrointestinal System Endoscopy Results. KU Faculty of Med J 2004; 6: 10-2.

42. Yılmaz N, Bölükbas C, Bölükbas F, et al. Our upper gastrointestinal endoscopy findings; Harran University. Turk J Gastroenterol 2003; 14: 198
43. Yükselen V, Ötürk B, Karaoğlu A, et al. Diagnostic distribution of upper gastrointestinal endoscopic examinations performed in Adnan Menderes University Faculty of Medicine, Department of Gastroenterology by years. Turk J Gastroenterol 2003; 14: 489. 